\title{
PEMANTAUAN KUALITAS AIR DANAU SEMAYANG DAN DANAU MELINTANG DI KABUPATEN KUTAI KARTANEGARA MENGGUNAKAN SISTEM ONLINE MONITORING
} \author{
Using Online Monitoring System \\ Oleh: \\ Heru Dwi Wahjono \\ Pusat Teknologi Lingkungan, BPPT
}

Water Quality Monitoring for Semayang Lake and Melintang Lake in Kutai Kartanegara District

\begin{abstract}
Abstrak
Danau Semayang dan Danau Melintang di Kabupaten Kutai Kartanegara, Kalimantan Timur merupakan salah satu danau terbesar yang ada di Indonesia. Kedua danau yang berada di Daerah Aliran Sungai Mahakam ini berperan penting bagi kegiatan ekonomi dan ekologi di wilayah provinsi Kalimantan Timur. Selain menjadi sumber penghidupan bagi nelayan di sekitar danau, juga menjadi habitat bagi mamalia air tawar yang hampir punah, yaitu ikan Pesut Mahakam. Dengan adanya penebangan hutan secara liar di sekitar danau, banyak terjadi banjir jika hujan dan pencemaran air dengan bertambahnya sedimen yang masuk ke perairan danau. Di sebagian wilayah juga memperoleh dampak dari kegiatan transportasi industri pertambangan batu bara di sekitar Sungai Mahakam. Semua ini menyebabkan terjadinya pendangkalan hampir di seluruh permukaan danau dan mengakibatkan berkurangnya potensi perikanan yang ada serta semakin punahnya ikan Pesut Mahakam. Untuk mengendalikan pencemaran di kedua danau, BPLHD Kabupaten Kutai Kartanegara telah menerapkan teknologi online monitoring untuk memantau kualitas perairan danau di empat titik lokasi. Hasil pemantauannya digunakan untuk mendukung pemerintah daerah dalam mengambil kebijakan pengendalian pencemaran di kedua danau tersebut.
\end{abstract}

Kata Kunci : Teknologi online monitoring kualitas air, sistem pemantauan kualitas perairan danau, teknologi GSM dan SMS, multiprobe sensor, sistem telemetri.

\begin{abstract}
Semayang Lake and Melintang Lake in Kutai Kartanegara district, East Kalimantan is one of the biggest lake in Indonesia. Both lakes are located in the Mahakam River Basin and has an important role for economic and ecological activities in the Province of East Kalimantan. In addition to being a source of livelihood for fishermen around the lake, is also as habitat for freshwater mammals Pesut Mahakam that are endangered. Illegal logging in the forest around the lake, causing floods when it rains and water pollution will increase with sediment flowing into the lake. In some areas also get the impact of transportation activities of coal mining industry around the Mahakam River. All this causes silting almost the entire surface of the lake, lead to a reduction of existing fishery potential and cause extinction of Pesut Mahakam. To control pollution in the lake, local government of Kutai Kartanegara has implemented an online monitoring technology to monitor the water quality of the lake in four point location. Monitoring results are used to support local goverment in taking pollution control policies in both lakes.
\end{abstract}

Keywords: Water quality online monitoring system, lake water quality monitoring system, GSM and SMS technology, multiprobe sensor, telemtry system.

\section{PENDAHULUAN}

\subsection{Latar Belakang}

Danau Semayang dan Danau Melintang adalah danau-danau yang berlokasi di Daerah Aliran
Sungai (DAS) Mahakam di Kabupaten Kutai Kartanegara, Kalimantan Timur. Danau Semayang memiliki luas sekitar 13.000 hektare dan berada di sebelah kiri sungai Mahakam dan bersebelahan dengan Danau Melintang yang memiliki luas sekitar 
11.000 hektar yang terletak disebelah kanan Mahakam. (Wikipedia, 2015)

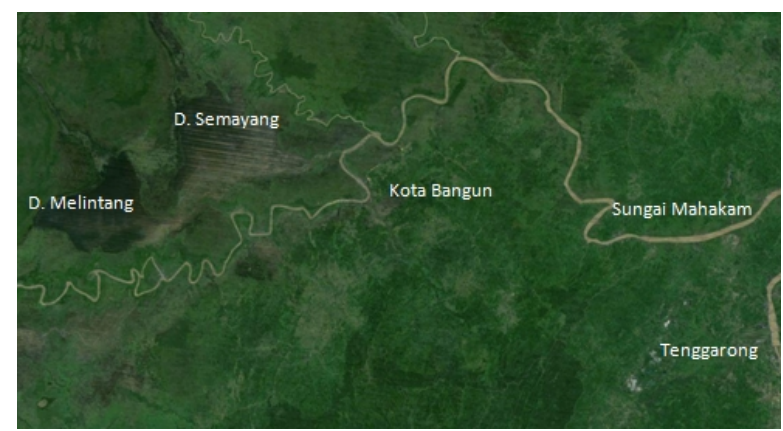

Gambar 1 : Lokasi Danau Melintang dan Danau Semayang di Kalimantan Timur.

Danau Semayang yang terdapat di Daerah Mahakam Tengah (DMT), merupakan salah satu lingkungan lahan basah terbesar di Kalimantan. Kedalaman Danau Semayang $13 \mathrm{~m}$ dengan volume danau 390.000.000 m3. Inlet dan outlet Danau Semayang adalah Sungai Belayan dan Sungai Pela. Keanekaragaman hayati di sekitar danau Semayang cukup tinggi, termasuk biota perairan maupun terestrial, juga sumber daya air yang melimpah untuk berbagai aktivitas masyarakat sekitar. Bisa dikatakan Danau Semayang merupakan zona yang memiliki kekayaan plasma nutfah dan wilayah ekologis yang mempunyai nilai ekonomi potensial untuk berbagai kegiatan. (Limnologi, 2014)

Danau Melintang dinamakan melintang karena danau ini melintang (Kenohan) di desa yang ada di sekitar danau tersebut. Di danau ini ada beberapa desa terapung yang berdiri di atas tiang maupun dirakit-rakit. Salah satunya adalah Desa Melintang yaitu sebuah desa indah di tepi Danau Melintang, yang berada di Kecamatan Muara Wis, Kabupaten Kutai Kartanegara. Danau ini banyak digunakan sebagai tempat pengembang biakan ikan air tawar. Pesut juga ada di perairan danau ini, meskipun jumlahnya semakin menyusut akibat pendangkalan danau. (Wikipedia, 2015)

Penebangan hutan secara liar yang terjadi di hutan sekitar danau, menyebabkan terjadinya banjir jika musim hujan datang dan airnya mengalir masuk ke dalam danau dengan membawa sedimen dalam jumlah yang banyak. Di sebagian wilayah juga memperoleh dampak dari kegiatan transportasi industri pertambangan batu bara di sekitar Sungai Mahakam. Semua ini menyebabkan terjadinya pendangkalan hampir di seluruh permukaan kedua danau dan mengakibatkan berkurangnya potensi perikanan yang ada serta semakin punahnya ikan Pesut Mahakam yang hidup di dalamnya. Tabel berikut ini menunjukkan status kualitas air Danau Semayang dan Melintang. (Limnologi, 2014)
Tabel 1 : Status Mutu Kualitas Air Danau Semayang dan Danau Melintang.

\begin{tabular}{|l|c|c|c|}
\hline Parameter & Satuan & D. Semayang & D. Melintang \\
\hline Warna & - & coklat kuning & coklat kuning \\
\hline Kecerahan & - & $25-38$ & $25-38$ \\
\hline Suhu & oC & $=$ suhu udara & $=$ suhu udara \\
\hline $\mathrm{pH}$ & umhos/ppm & $4,5-5,5$ & $4,5-5,5$ \\
\hline DHL & $\mathrm{ppm}$ & $15-33$ & $26-44$ \\
\hline Phosphat & $\mathrm{ppm}$ & $0,8-1,3$ & $2,0-3,3$ \\
\hline Nitrat & $\mathrm{ppm}$ & $0,8-5,3$ & $5,0-7,8$ \\
\hline DO & $\mathrm{ppm}$ & $1,3-5,0$ & $2,4-5,2$ \\
\hline BOD & $\mathrm{ppm}$ & $0,9-1,9$ & $1,5-1,9$ \\
\hline Organik & $\mathrm{ppm}$ & $15,8-27,5$ & $27,2-33,7$ \\
\hline
\end{tabular}

Untuk mengendalikan pencemaran di kedua danau, Badan Lingkungan Hidup Daerah Kota Tenggarong, Kabupaten Kutai Kartanegara telah menerapkan sistem online monitoring berbasis teknologi GSM dan SMS untuk memantau kualitas perairan danau di 4 (empat) titik lokasi di dalam wilayah perairan kedua danau. Hasil pemantauannya diharapkan dapat digunakan untuk mendukung pemerintah daerah dalam mengambil kebijakan pengendalian pencemaran di kedua danau tersebut.

\subsection{Tujuan Dan Sasaran}

Tujuan dari kegiatan adalah menerapkan teknologi online monitoring kualitas air secara online dan realtime di empat lokasi pemantauan di wilayah perairan Danau Semayang dan Danau Melintang. Adapun sasaran dari kegiatan ini adalah mengetahui kondisi dan status kualitas air di kedua danau tersebut.

\subsection{Metodologi}

Metodologi yang digunakan untuk melaksanakan kegiatan pemantauan kualitas air Danau Semayang dan Danau Melintang secara online adalah sebagai berikut :

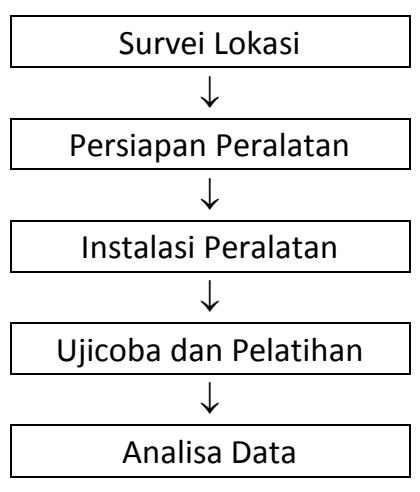

Gambar 2 : Metodologi Kegiatan. 
a. Survei lokasi, dilakukan dengan mengamati lokasi tempat pemasangan sistem peralatan online monitoring. Data yang diperlukan adalah koordinat lokasi, kedalaman danau dan teknis pengamanan peralatan di lapangan.

b. Persiapan peralatan, dilakukan dengan mempersiapkan peralatan online monitoring yang akan dipasang, yaitu pengadaan sensor digital, pembuatan data logger, pengadaan sistem komputer data center dan instalasi sistem software online monitoring kualitas air.

c. Instalasi peralatan, dilakukan di 4 (empat) titik lokasi yang telah ditentukan dan dinilai aman untuk menempatkan sensor dan data logger. Sensor dimasukkan ke dalam casing pengaman dan harus selalu tercelup ke dalam air sedangkan data logger dan GSM modem tidak boleh basah atau lembab karena air.

d. Ujicoba pengoperasian dan pelatihan operator dilakukan bersamaan di pusat data yang berlokasi di Kantor BLH Kota Tenggarong, Kabupaten Kukar, Provinsi Kalimantan Timur. Pelatihan yang diberikan meliputi pengoperasian sistem software, perawatan dan kalibrasi sensor, serta pengamatan hasil pemantauan.

e. Analisa data dilakukan setelah mendapatkan hasil pemantauan kualitas air di keempat titik lokasi pemasangan di kedua danau. Analisa dilakukan dengan mengamati hasil pengukuran baik dalam bentuk angka maupun grafik.

\section{PEMBAHASAN}

\subsection{Survei Lokasi}

Survei penentuan lokasi dilaksanakan dari Kota Bangun menelusuri Sungai Mahakam masuk ke arah dalam muara Sungai Pela terus menuju Danau Melintang dan Danau Semayang. Beberapa lokasi pemberhentian pada saat survei adalah ditunjukkan oleh nomor (1) (Kota Bangun) nomor (8) (lokasi terjauh) pada gambar peta di bawah ini.

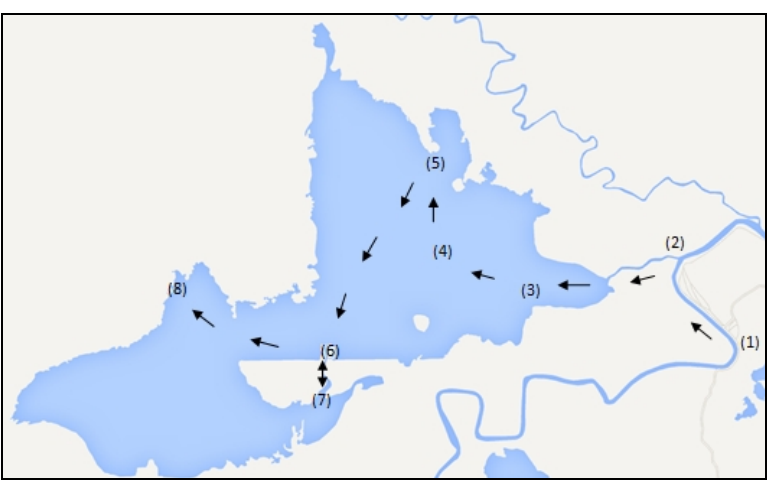

Gambar 3 : Beberapa Titik Pemberhentian Lokasi Survei.
Dari hasil survei dapat diketahui bahwa secara umum kedua danau tidak terlalu dalam karena telah mengalami pendangkalan yang kemungkinan sudah terjadi sejak lama. Diperkirakan lokasi untuk penempatan sistem peralatan pemantuan kualitas air memiliki kedalaman sekitar $2 \sim 5$ meter. Survei dilakukan pada saat kondisi air surut, sehingga pada saat air pasang kedalaman lokasi bisa lebih dari 5 meter. Citra satelit di bawah ini menunjukkan kedua danau telah berwarna coklat yang berarti permukaan tanah/lumpur dan dapat diartikan telah terjadi pendangkalan di kedua danau tersebut.

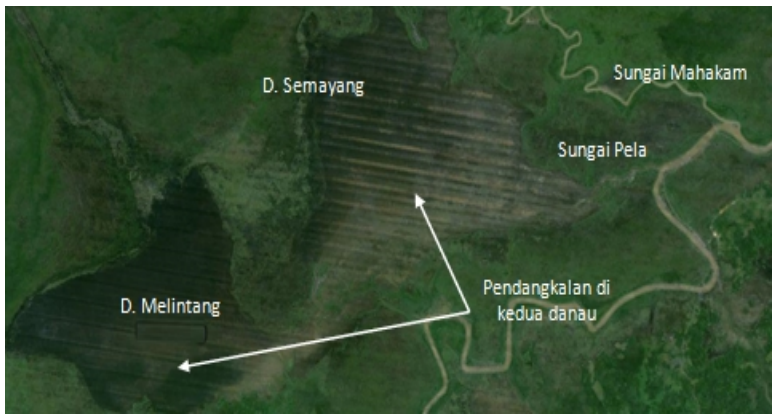

Gambar 4 : Foto Satelit Menunjukkan Pendangkalan di Kedua Danau.

Dari gambar di atas dapat diketahui bahwa air Sungai Mahakam yang masuk melalui Sungai Pela ke arah dalam kedua danau perlu dipantau di beberapa titik lokasi sebelum masuknya air ke dalam dan titik lokasi keluarnya air dari kedua danau tersebut. Hal ini perlu dilakukan untuk mengetahui kecenderungan kualitas air yang ada di titik lokasi tersebut. Lokasi pemasangan sistem pemantauan kualitas air online yang telah ditetapkan berjumlah 4 (empat) titik lokasi yang penentuannya didasarkan beberapa kategori pemilihan lokasi, yaitu :

- Memiliki kedalam air yang cukup pada saat surut.

- Berada di inlet atau outlet kedua danau yang berada di muara desa.

- Berada di lokasi cakupan wilayah jaringan GSM lokal (Telkomsel).

- Berada di lokasi yang aman dari pencurian.

- Penduduk setempat bersedia mengawasi dan merawatan area sekitar lokasi peralatan.

Berikut ini adalah nama keempat lokasi pemasangan sistem peralatan yang telah ditentukan pada saat melaksanakan kegiatan survei.

A. Lokasi 1 :

- Nama Stasiun : Muara Pela

- ID Stasiun : BLH1

- Lokasi Stasiun : di muara Sungai Pela

- Koordinat : $00^{\circ} 14,241^{\prime} \mathrm{LS} ; 116^{\circ} 33,984^{\prime}$ BT

- Kedalaman : $\pm 3 \sim 6$ meter 
B. Lokasi 2 :

- Nama Stasiun : Desa Semayang

- ID Stasiun : BLH2

- Lokasi Stasiun : di muara Desa Semayang

- Koordinat : $00^{\circ} 11,243^{\prime} \mathrm{LS} ; 116^{\circ} 27,306^{\prime} \mathrm{BT}$

- Kedalaman : \pm 5 meter

C. Lokasi 3 :

- Nama Stasiun : Desa Melintang

- ID Stasiun : BLH3

- Lokasi Stasiun : di Tanjung Sebembem

- Koordinat : $00^{\circ} 17,760^{\prime} \mathrm{LS} ; 116^{\circ} 24,317^{\prime}$ BT

- Kedalaman : \pm 2 meter

D. Lokasi 4 :

- Nama Stasiun : Desa Neggelamg

- ID Stasiun : BLH4

- Lokasi Stasiun : di muara Desa Nenggelam

- Koordinat : $00^{\circ} 14,967$ LS ; $116^{\circ} 20,136^{\prime}$ BT

- Kedalaman : \pm 2 meter

Untuk memantau status kualitas air di keempat lokasi tersebut perlu disiapkan pusat data di kantor BLH Kota Tenggarong yang berjarak kurang lebih 3 jam dari Kota Bangun atau 6 jam dari lokasi titik terjauh (BLH4).

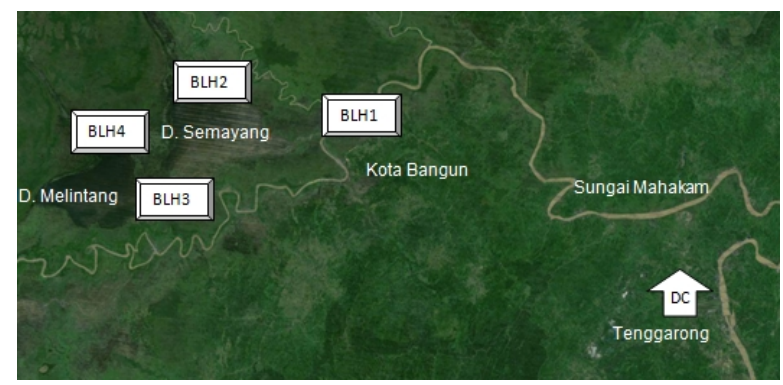

Gambar 5 : Lokasi Pemasangan Stasiun Pemantauan dan Pusat Data.

\subsection{Pemilihan Operator Jaringan GSM}

Untuk memilih operator jaringan komunikasi dilakukan pengujian terhadap kekuatan sinyal GSM di lokasi stasiun monitoring di area danau dan lokasi pusat data di Kota Tenggarong. Pengujiannya dilakukan secara manual, yaitu dengan menggunakan perangkat smartphone dan bantuan aplikasi android 'Open Signal' dan 'Signal Meter'. Pengujian dilakukan terhadap beberapa operator seluler dengan sim card Simpati, AS, Halo, 3, XL, dan IM3. Untuk konfirmasi dilakukan survey juga ke beberapa penduduk dengan menanyakan secara langsung operator GSM yang digunakan oleh mereka. Hasil survey pemilihan operator GSM ditetapkan untuk menggunakan Sim Card Kartu AS dari operator GSM Telkomsel. (Heru \& Bayu, 2006)

\subsection{Persiapan Peralatan}

Persiapan peralatan dilakukan dengan mengadakan komponen peralatan online monitoring, yaitu remote terminal unit (RTU) dan pusat data seperti tabel di bawah ini. (Bayu \& Heru, 2013)

Tabel 2 : Komponen Peralatan Online Monitoring.

\begin{tabular}{|l|l|c|}
\hline No. & \multicolumn{1}{|c|}{ Komponen Peralatan } & Jumlah \\
\hline 1. & Smart Data logger & 4 unit \\
\hline 2. & Batere / aki kering 12VDC 12AH & 4 unit \\
\hline 3. & Soler cell 20WP, kabel dan bracket & 4 set \\
\hline 4. & Multiprobe sensor (11 parameter) & 4 paket \\
\hline 5. & Pipa pelindung sensor & 4 set \\
\hline 6. & Bangunan pelindung (rumah rakit) & 4 unit \\
\hline 7. & Komputer data center & 1 unit \\
\hline 8. & GSM Modem & 1 unit \\
\hline 9. & Sistem software & 1 paket \\
\hline
\end{tabular}

\subsubsection{Smart Data Logger}

Smart data logger yang disiapkan memiliki fitur utama, yakni sistem pengiriman data berbasis SMS dan dapat lebih dari 164 karakter, interval waktu pengiriman dapat disetting dan dimonitoring dari pusat data, interval waktu pengukuran kualitas untuk early warning system hanya 60 detik, status memori dan status pengiriman data dapat dimonitoring dari pusat data, serta memiliki onsite display untuk menampilkan hasil pengukuran setiap saat di lokasi. (Bayu \& Heru, 2013)

Adapun spesifikasi teknis sistem data logger yang dikembangkan adalah (Bayu \& Heru, 2013) :

- Serial RS-232 port : 1 main, 3 slave

- 8 channel analog port

- 8 bit optocoupler TTL input, extendable to 40 bit

- 4 bit Transistor output, extendable to 20 bit

- 256 kByte flash memori

- Real Time Clock dan

- Dilengkapi PLC untuk EWS

Gambar berikut ini adalah keempat smart data logger yang dimasukkan ke dalam box panel aluminium dan siap dipasang di lokasi pemantauan.

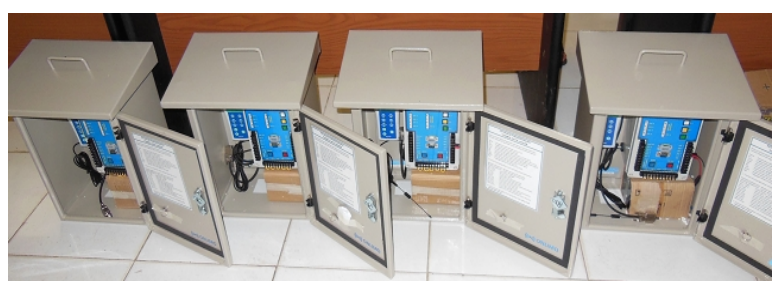

Gambar 6 : Smart Data Logger. 


\subsubsection{Solar Cell dan Batere / Aki Kering}

Untuk pengoperasian peralatan digunakan sistem kelistrikan tenaga surya / solar cell. Energi listrik yang berasal dari solar cell akan disimpan ke dalam batere kering (12volt 12Ah) melalui regulator yang dapat mengendalikan status pengisian batere tersebut. Pengisian hanya akan dilakukan bila tegangan pada aki kering kurang dari 11.4 volt dan akan berhenti otomatis bila tegangan telah mencapai 13.9 volt. (Bayu \& Heru, 2013)
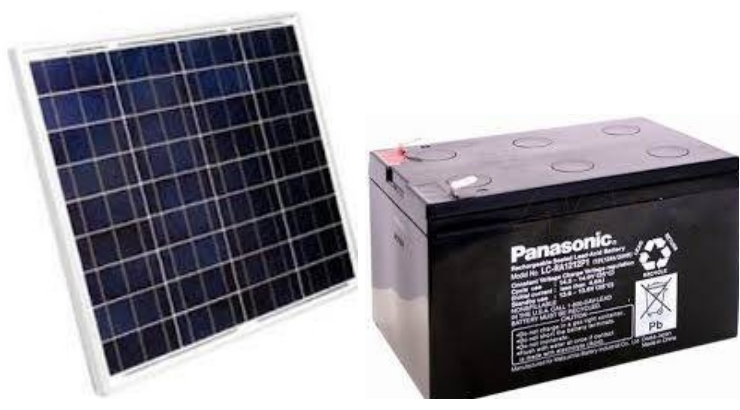

Gambar 7 : Batere Kering dan Solar Cell.

\subsubsection{Multiprobe Sensor DKK-TOA WQC-24 dan Pipa PVC Pelindung Sensor}

Multiprobe digital sensor DKK-TOA WQC-24 adalah sensor kualitas air yang terdiri dari beberapa probe sensor yang mampu mengukur beberapa parameter sekaligus secara bersamaan. Ada 9 jenis parameter kualitas air yang dapat diukur, yakni : (1). Suhu [oC], (2). Conductivity $[\mathrm{mS} / \mathrm{cm}],(3) . T D S[\mathrm{~g} / \mathrm{l}]$, (4). Salinity [ppt], (5). DO [mg/l], (6). pH, (7). SwSG [ot], (8). Turbidity [mg/l], dan ORP [mV].

Selanjutnya untuk keperluan perawatan dan kalibriasi sensor, disediakan juga beberapa larutan standar pH 4 dan 10 yang digunakan untuk melakukan kalibrasi parameter $\mathrm{pH}$, serta larutan $\mathrm{KCL}$ yang digunakan untuk pemeliharaan sensor DO. Gambar berikut ini adalah keempat unit multiprobe sensor DKK-TOA tipe WQC-24 dengan perlengkapan larutan standar untuk kalibrasi sensornya.

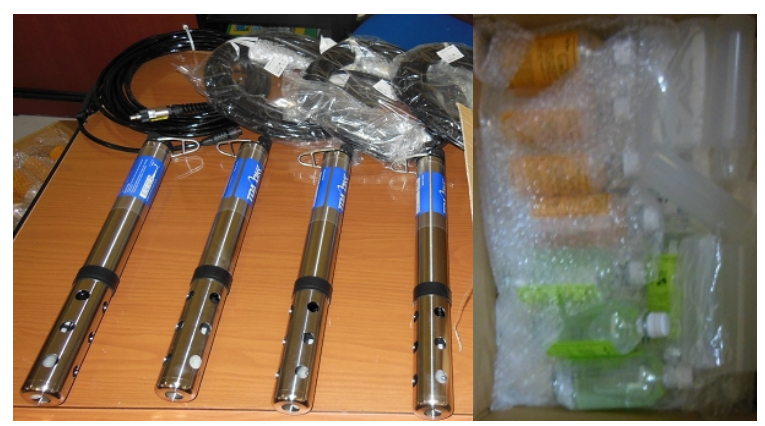

Gambar 8 : Multiprobe Sensor dan Perlengkapan Kalibrasi.

Aksesori perpipaan harus disesuai dengan kondisi pemasangan sensor di lokasi. Sistem perpipaan dipersiapkan untuk melindungi perangkat sensor dari kotoran atau sampah yang ada di danau dan melindungi kabel data yang terbentang dari sensor menuju data logger. Pipa yang digunakan adalah berbahan PVC dan berdiameter 3". Pipa pelindung sensor dibuat berlubang agar air mudah mengalir melewati sensor seperti pada berikut ini.

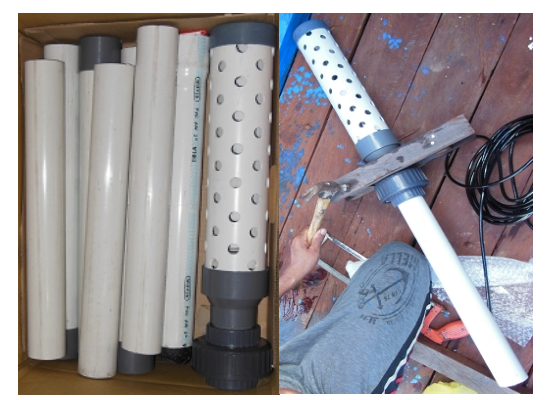

Gambar 9 : Pipa PVC 3" Pelindung Sensor.

\subsubsection{Bangunan Pelindung Rumah Rakit}

Pemasangan peralatan online monitoring di Danau Semayang dan Danau Melintang memerlukan bangunan pelindung yang berbeda dengan bangunan pelindung peralatan telemetri pada umumnya yang biasanya terinstalasi di daratan. Untuk melindungi seluruh peralatan online monitoring di kedua danau dibuat bangunan pelindung berupa rumah rakit yang dapat mengapung naik turun sesuai kondisi pasang surut air danau. Bangunan pelindung rumah rakit dibuat dari bahan kayu yang diletakkan di atas ponton (tabung plastik berisi udara) agar dapat mengapungkan seluruh bangunan ke permukaan air. Bangunan pelindung yang dibuat berdimensi 3 meter x 4 meter, dengan rumah-rumahan berukuran 1 meter x 1,2 meter seperti gambar di bawah ini.

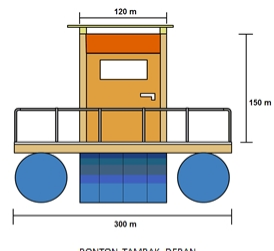

PONTON TAMPAK DEPAN

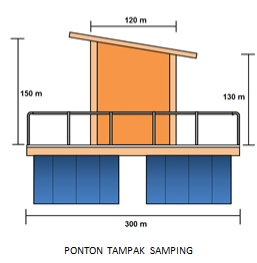

Gambar 10 : Rancangan Bangunan Pelindung Rumah Rakit. 
Gambar berikut ini adalah rancangan bangunan rumah rakit dalam bentuk 3 dimensi. Rancangan bangunan rumah rakit ini mampu menampung 10 orang dewasa di atasnya.

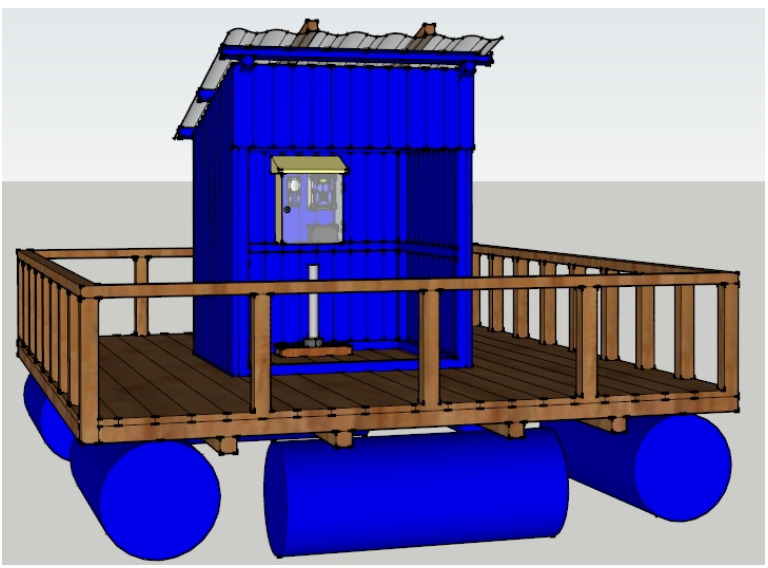

Gambar 11 : Bangunan Pelindung Rumah Rakit.

\subsubsection{Komputer Data Center dan GSM Modem}

Selain perangkat remoter terminal unit (RTU) yang dipasang di keempat lokasi pemantauan, pada kantor BLH Kutai Kartanegara disiapkan personal komputer untuk pusat data. Komputer data center ini dipilih dengan spesifikasi teknis server agar mampu beroperasi selama 24 jam tanpa henti, sehingga diperlukan sistem pendingin dan uninterupted power supplay / UPS yang lebih baik. Sebagai media komunikasi antara komputer server dengan keempat RTU di stasiun pemantauan, digunakan GSM modem. Gambar berikut ini adalah komputer data center dengan peralatan GSM modem yang sudah dipasang.

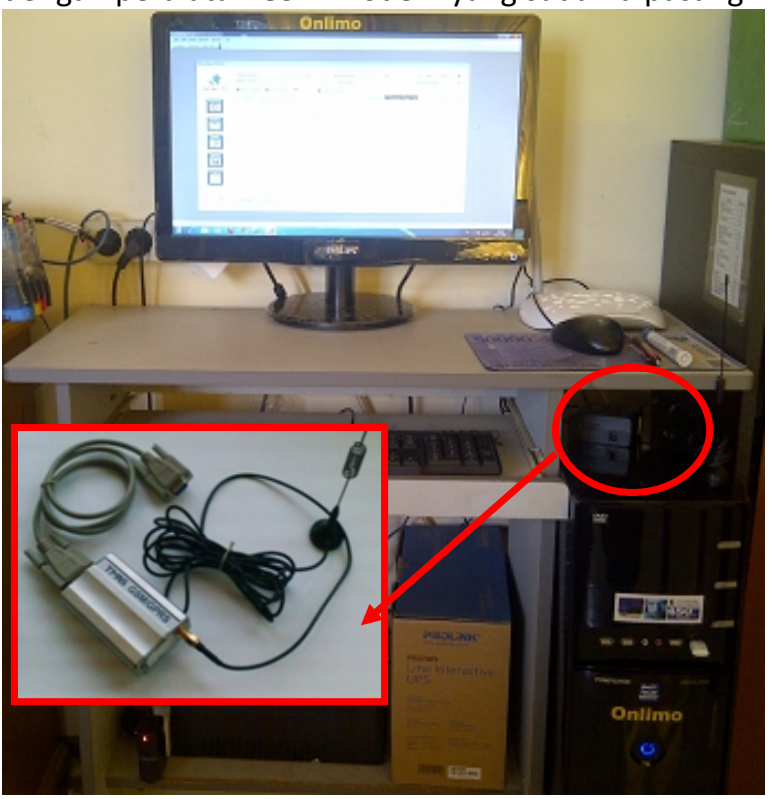

Gambar 12 : Komputer Data Center dan GSM Modem.

\subsubsection{Sistem Software Online Monitoring}

Ada dua sistem software online monitoring yang disiapkan, yaitu aplikasi SMS Gateway dan dan aplikasi Database Online Monitoring. Kedua apliaksi ini dirancang dan dikembangkan berbasis sistem Windows agar dapat beroperasi secara bersamasama dengan integrasi seluruh peralatan online monitoring yang dipasang. Aplikasi SMS Gateway digunakan mengendalikan pengiriman data melalui pesan singkat / SMS, sedangkan aplikasi database digunakan untuk pengelolaan dan pelaporan data monitoring kualitas air (Heru Dwi W., 2013).

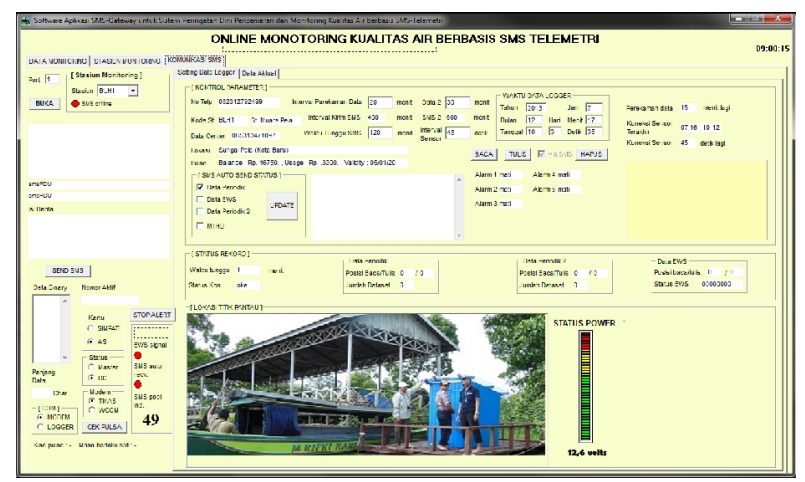

Gambar 13 : Software SMS Gateway.

Gambar di atas adalah perangkat lunak SMS gateway yang dikembangkan dengan spesifikasi, yaitu memiliki fitur multi station monitoring, pengendalian jarak jauh dengan perintah AT melalui sistem SMS, memiliki fitur peringatan dini (Early Warning System), dapat mengatur nilai baku mutu kualitas air, memiliki fitur multi user SMS dan EWS, dapat mengatur interval waktu pengukuran, dapat mengatur interval waktu pengiriman data, perekaman data dalam format $\mathrm{mdb}$ dan txt (pipe delimited), memiliki informasi status batere, memori dan sisa pulsa untuk kartu prabayar, memiliki fitur visual peringatan dini di komputer (red blink), dan dapat merespon permintaan data oleh pengguna yang terdaftar.

Gambar di bawah ini adalah perangkat lunak database online monitoring kualitas air yang dikembangkan dengan spesifikasi teknis, yaitu : dapat mengelola data stasiun dan kualitas air, memiliki fitur penggunaan bersama file oleh aplikasi SMS Gateway melalui file data dalam format teks, dapat memantau data secara online realtime, dapat menampilkan data pengukuran dalam bentuk angka dan grafik analisa, memiliki modul laporan ringkas, detail dan lengkap, memiliki modul dokumen elektronik online manual, regulasi dan baku mutu, memiliki fitur penelusuran data harian, bulanan, dan stasiun, serta memiliki fitur untuk export data ke dalam format MS Excel. 


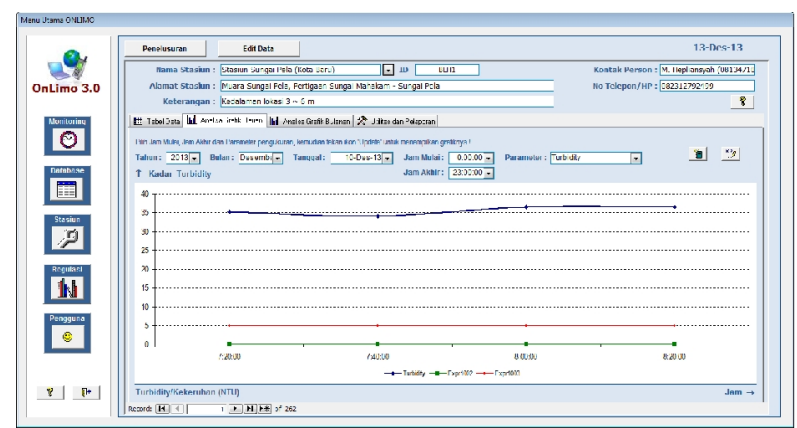

Gambar 14 : Software Database Kualitas Air.

\subsection{Instalasi/Pemasangan Peralatan}

Instalasi pemasangan dimulai dari lokasi yang terjauh, yaitu di muara desa Nenggelam yang berada 3 jam dari Kota Bangun. Pemasangan dimulai dengan membawa rumah rakit ke posisi koordinat yang telah ditentukan. Kegiatan pemasangan dimulai dari pemasangan panel surya di bagian atap rumah rakit, berikutnya memasang box panel control dan data logger di dinding rumah rakit bagian dalam dan terakhir mencelupkan sensor ke dalam lubang yang telah disiapkan seperti pada gambar-gambar di bawah ini.

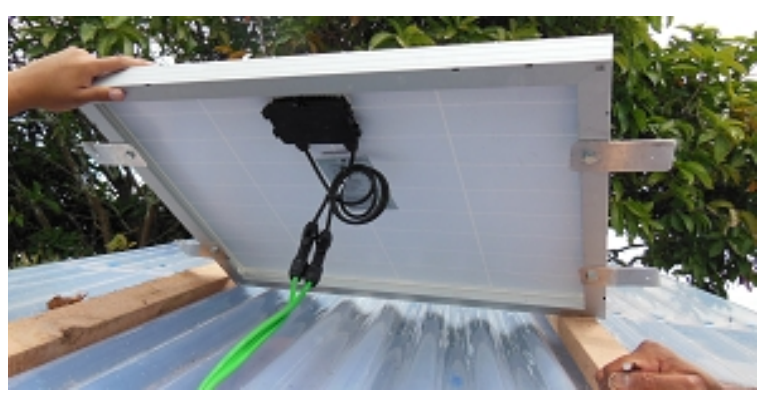

Gambar 15 : Pemasangan Solar Cell.

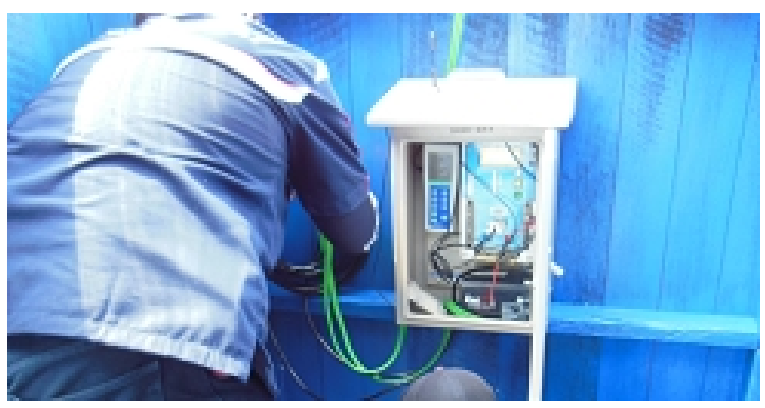

Gambar 16 : Pemasangan Box Panel dan Data Logger.

Sebelum dicelupkan, sensor dimasukkan ke dalam casing pelindung berlubang dari bahan PVC 3" terlebih dahulu, kemudian dijepit oleh kayu yang dibuat sedemikian rupa agar casing pelindung hanya tercelup di bagian bawahnya saja. Berikut ini adalah gambar pipa PVC yang telah dipasang pada kayu penjepit (kiri) dan posisi pencelupan bagian pipa berlubang ke dalam air (kanan)
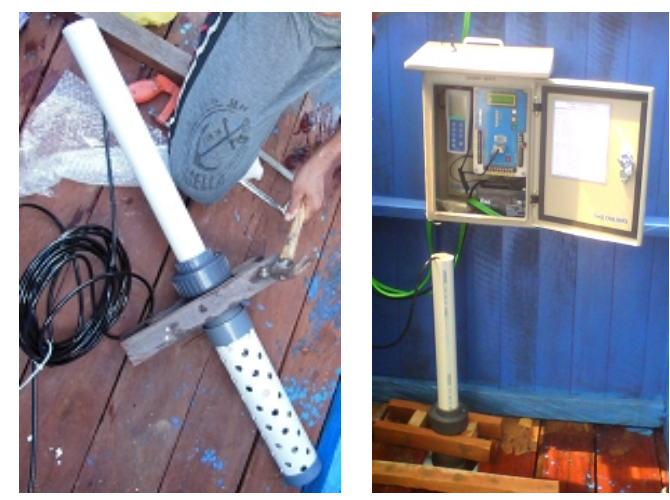

\section{Gambar 17 : Pemasangan Sensor dan Casing Pelindung PVC.}

Setiap selesai pemasangan RTU di keempat lokasi pemasangan dilakukan ujicoba komunikasi dengan pengecekan status sistem data logger. Pengujian dilakukan dengan menggunakan perangkat modem GSM dengan perangkat laptop yang sudah diinstalasikan sistem software SMS gateway seperti gambar di bawah ini.

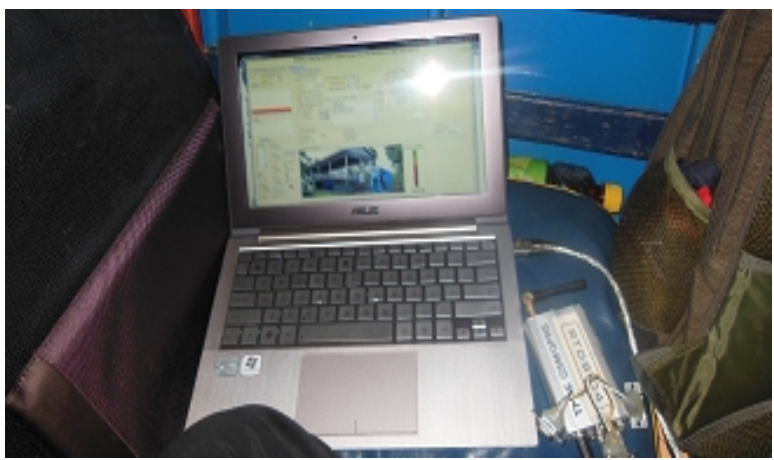

Gambar 18 : Pengujian Status Komunikasi Perangkat RTU di Masing-Masing Lokasi Pemasangan .

\subsection{Konfigurasi Sistem}

Setting konfigurasi sistem untuk melakukan pengukuran ditentukan dengan beberapa parameter konfigurasi, yaitu : interval waktu pengukuran 3600 detik (60 menit) dan interval peringatan dini 60 detik (1 menit). Dalam sehari akan diperoleh data hasil pengukuran kualitas air sebanyak 24 record data, sedangkan keterlambatan waktu peringatan dini adalah 60 detik. Interval pengiriman data pengukuran yang dilakukan setiap 3 jam untuk menghemat biaya pengiriman data melalui SMS. Jadi dalam sehari ada 8 kali biaya transaksi pengiriman data pengukuran. Walaupun pengiriman data dilakukan 3 jam sekali, namun setiap saat data logger tetap dapat mengirimkan data peringatan dininya apabila hasil 
pengukurannya tidak memenuhi baku mutu yang telah ditentukan (Heru Dwi W., 2013).

Konfigurasi nilai baku mutu yang ditetapkan untuk pemantuan kualitas air di danau Semayang dan danau Melintang disesuaikan dengan peraturan daerah yang berlaku di Kabupaten Kutai Kartanegara, yaitu Peraturan Daerah Provinsi Kalimantan Timur No. 2 Tahun 2011 Tentang Pengendalian Kualitas Air dan Pengendalian Pencemaran Lingkungan. Pada Lampiran VI tabel peruntukan dan kelas air pada sungai lintas kabupaten/kota di Kalimantan Timur nomor urut 1 disebutkan bahwa Sungai Mahakam merupakan sumber air yang berada pada wilayah administrasi Kutai Barat, Kutai Kertanegara dan Samarinda berada pada kategori kelas mutu air I. Sehingga danau Semayang dan danau Melintang yang bermuara pada Sungai Mahakam juga dapat dikategorikan pada kelas mutu air I (Gubernur Kaltim, 2011).

Pada Lampiran $\mathrm{V}$ tabel baku mutu air pada sumber air berdasarkan kelas telah ditentukan nilai baku mutu air beberapa parameter kualitas air untuk empat kelas mutu air. Baku mutu air kelas I yang digunakan sebagai nilai maksimal atau minimal pada setting konfigurasi pengukuran, yaitu : Temperatur $20{ }^{\circ} \mathrm{C} \sim 30{ }^{\circ} \mathrm{C}$, Konduktifitas maksimal $50 \mathrm{mS} / \mathrm{cm}$, TDS maksimal $30 \mathrm{~g} / \mathrm{l}$, Salinitas maksimal $30 \mathrm{ppt}$, DO minimal $3 \mathrm{mg} / \mathrm{l}$, dan kadar keasaman / pH $6 \sim 8$ (Gubernur Kaltim, 2011).

\subsection{Pengoperasian RTU dari Pusat Data}

Agar keempat RTU yang dipasang di empat lokasi di Danau Semayang dan Melintang dapat dikendalikan oleh komputer pusat data, perlu didaftarkan nomor ID dan nomor simcard dari keempat perangkat RTU tersebut pada aplikasi SMS gateway seperti pada gambar di bawah ini. Tabel berikut ini adalah ID Stasiun dan nomor simcard data logger yang terpasang.

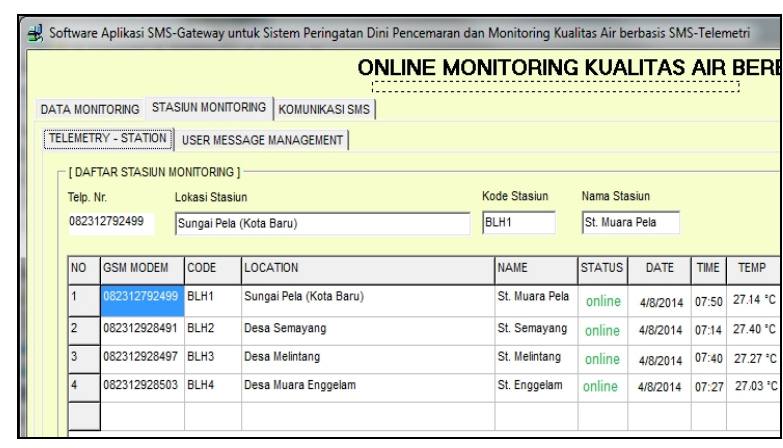

Gambar 19 : Registrasi Keempat RTU pada Aplikasi SMS Gateway.
Tabel 3 : ID Stasiun dan Nomor Simcard RTU.

\begin{tabular}{|l|l|l|c|}
\hline No & ID. Stasiun & \multicolumn{1}{|c|}{ Nama Stasiun } & No. GSM \\
\hline 1. & BLH1 & Muara Pela & 082312792499 \\
\hline 2. & BLH2 & Desa Semayang & 082312928491 \\
\hline 3. & BLH3 & Desa Melintang & 082312928497 \\
\hline 4. & BLH4 & Desa Nenggelam & 082312928503 \\
\hline 5. & DC & Data Center & 085313471097 \\
\hline
\end{tabular}

Pengoperasian sistem komunikasi dimulai dengan mengaktifkan keempat data logger yang sudah terpasang. Indikator bahwa data logger bekerja dengan baik adalah berkedipnya lampu led merah, hijau dan kuning pada data logger secara bergantian dengan interval waktu yang sama dan berulang. Jika salah satu lampu led mati atau nyala terus menurus menandakan ada masalah pada sistem data logger. Selanjutnya untuk menguji komunikasi antara data logger dan pusat data, dilakukan prosedur cek status ke keempat nomor simcard pada data. Dibutuhkan waktu 1 menit untuk mendapatkan informasi status data logger. Jika proses komunikasi melalui SMS berhasil, maka pada SMS Gateway akan muncul informasi data status operasi data logger seperti pada gambar di bawah.

Informasi penting dari window aplikasi SMS gateway adalah sebagai berikut :

- SMS AUTO SEND STATUS untuk mengetahui status otomasi pengiriman data. Jika kolom cek Data Periodik dan Data EWS tercentang berarti setting konfigurasi aktif atau sebaliknya.

- Interval Perekaman Data 60 menit berarti interval waktu pengukurannya 1 jam sekali.

- Interval Kirim SMS 180 menit berarti interval pengiriman data pengukuran setiap 3 jam sekali.

- Waktu Tunggu SMS 120 menit berarti waktu pengiriman data berikutnya adalah 2 jam lagi.

- Koneksi Sensor Setiap 45 detik berarti delay waktu peringatan dini adalah 45 detik.

Selain informasi di atas, masih banyak lagi data informasi yang diperoleh mengenai status data logger, yaitu WAKTU DATA LOGGER yang harus sinkron dengan waktu pada komputer pusat data, STATUS RECORD yang menunjukkan nomor posisi perekaman data pada memori data logger, dan Alarm sistem yang berjumlah 5 buah. Alarm sistem ini dapat diaktifkan untuk memberikan informasi kepada operator apabila ada komponen sistem monitoring yang hilang. Sistem akan mengirimkan SMS dan menyalakan alarm (red blink) pada aaplikasi SMS Gateway. Grafik STATUS POWER, nilai tegangannya dan angka baku mutu parameter juga dapat diketahui statusnya melalui window ini (Heru Dwi W., 2013). 


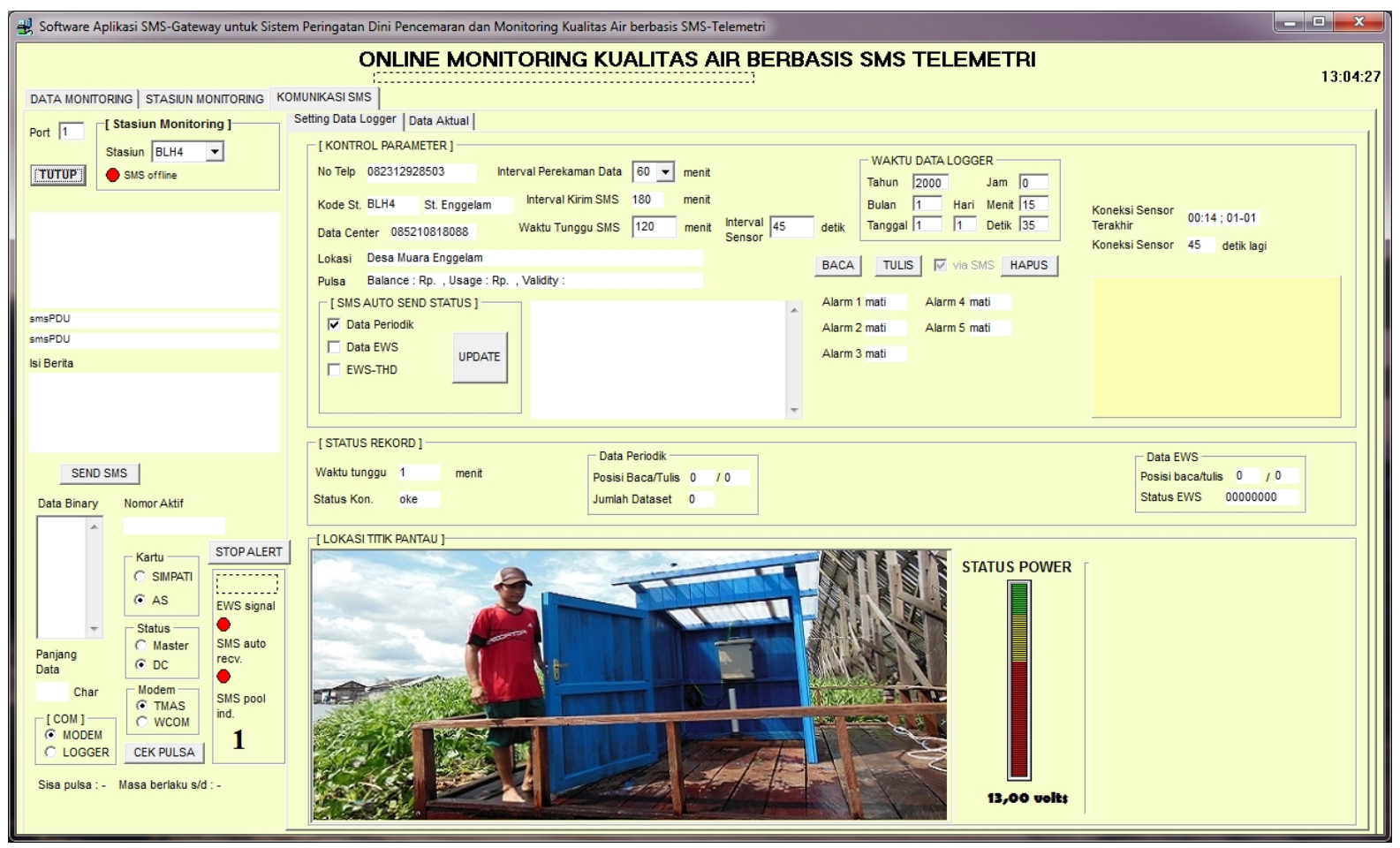

Gambar 20 : Status Pengoperasian RTU.

Gambar berikut ini menunjukkan data terakhir diterima oleh aplikasi SMS Gateway pada stasiun Muara Pela untuk semua parameter pengukuran berikut nilai tegangan aki kering yang tersedia.

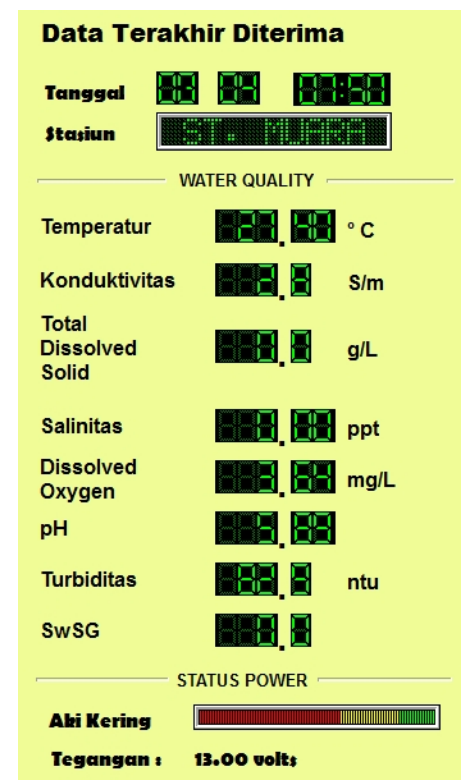

Gambar 21 : Informasi Data Terakhir Diterima oleh SMS Gateway.

Beberapa saat setelah status keempat RTU di empat lokasi terkirim, selanjutnya data periodik akan dikirimkan oleh data logger dari keempat RTU ke pusat data. Data akan disimpan oleh SMS gateway ke dalam file database dalam format txt (ASCII) dan mdb (Microsoft Access) seperti gambar di bawah ini.

\begin{tabular}{|c|c|c|c|c|c|c|c|c|c|c|c|c|}
\hline $\mathrm{Da}$ & ata-Pengukurar & txt & Notepad & & & & & & & & 口回 & $x$ \\
\hline Eile & Edit Format & $\underline{v}_{i}$ & Help & & & & & & & & & \\
\hline & $105 / 06 / 201$ & & $: 00: 00$ & & 32. & & & & & & 3.91 & A \\
\hline BLH4 & $05 / 06 / 201$ & & $00: 00$ & & 33. & & 0.7 & 0. & & 0.00 & 4.64 & \\
\hline $\begin{array}{l}\text { BLH4 } \\
\text { Bᄂ44 }\end{array}$ & {$\left[\begin{array}{l}05 / 06 / 201 \\
05 / 06 / 201\end{array}\right.$} & & $\begin{array}{l}00: 00 \\
000 \\
00\end{array}$ & & 84. & & $\begin{array}{l}0.7 \\
0.6\end{array}$ & 0.8 & & $\begin{array}{l}0.000 \\
0.00\end{array}$ & $\begin{array}{l}4.26 \\
4.37\end{array}$ & \\
\hline $\begin{array}{l}\text { BLH4 } \\
\text { BLH4 }\end{array}$ & $\mid \begin{array}{l}05 / 06 / 201 \\
05 / 06 / 201\end{array}$ & & $\begin{array}{l}: 00: 00 \\
00: 00 \\
00\end{array}$ & & 33. & & $\begin{array}{l}0.6 \\
0.7\end{array}$ & $\begin{array}{l}0.8 \\
0.0\end{array}$ & & $\begin{array}{l}0.00 \\
0.00\end{array}$ & $\begin{array}{l}\begin{array}{l}4.37 \\
3.81\end{array} \\
\end{array}$ & \\
\hline BLH4 & $05 / 06 / 20$ & & $: 00: 00$ & & 3. & & 0.7 & 0.0 & & 0.00 & 3.65 & \\
\hline BLH4 & $05 / 06 / 201$ & & $: 00: 00$ & & 3. & & $1.0 j$ & 0.0 & & 0.00 & $4.03 i$ & \\
\hline BLH4 & $105 / 06 / 201$ & & $\begin{array}{l}000 \\
000 \\
000\end{array}$ & & 2. & & $\begin{array}{l}0.6 \\
0.6\end{array}$ & $\begin{array}{l}0.8 \\
0.8\end{array}$ & & $\begin{array}{l}0.000 \\
0.00\end{array}$ & $\begin{array}{l}3.36 \\
3.37\end{array}$ & \\
\hline BLH4 & $05 / 06 / 201$ & & $00: 00$ & & 2. & & 1.0 & 0.0 & & 0.00 & 2.86 & \\
\hline $\begin{array}{l}\text { BLH4 } \\
\text { BLH4 }\end{array}$ & 05/06/201 & & $: 00: 00$ & & 2. & & 1.0 & 0.0 & & $0.00 \mid$ & 2.48 & \\
\hline & $\mid \begin{array}{l}05 / 06 / 201 \\
07 / 06 / 201\end{array}$ & & : $00: 00$ & & & & $\begin{array}{l}0.8 \\
1.3\end{array}$ & $\begin{array}{l}0.0 \\
0.0\end{array}$ & & 0.00 & 3.26 & \\
\hline & $07 / 06 / 201$ & & $00: 00$ & & 9. & & $\begin{array}{l}1.3 \\
1.5\end{array}$ & 0.8 - & & $\begin{array}{l}0.00 \\
0.00\end{array}$ & $\begin{array}{l}3.36 \\
1.36\end{array}$ & \\
\hline BLH2 & $07 / 06 / 201$ & & $: 00: 00$ & & 29. & & 1.5 & 0.0 & & 0.00 & 1.43 & $\square$ \\
\hline BLH4 & $05 / 06 / 201$ & 4 & $\begin{array}{l}: 00: 00 \\
: 00: 00\end{array}$ & & 30. & & $\begin{array}{l}0.81 \\
0.71\end{array}$ & $\begin{array}{l}0.8 \\
0.0\end{array}$ & & $\begin{array}{l}0.00 \mid \\
0.00\end{array}$ & $\begin{array}{l}2.12 \mid \\
2.18\end{array}$ & - \\
\hline 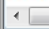 & & & & & & & & & & & & \\
\hline 亚 & periodic $\mathrm{Da}$ & ta : & able & & & & & & & & a & \\
\hline & Station & & $\mathrm{pH}$ & DO & & Cond & Turb & Temp & Sal & TDS & SwSG & 1 \\
\hline & $\mathrm{BLH} 3$ & & 75 & $427-3$ & & 32 & 131 & 30 & 0 & 0 & 0 & \\
\hline & & & & & & & & & & & & \\
\hline & BLH3 & & 6,17 & 4,29 & & 3 & 55,6 & 29,8 & 0 & 0 & 0 & \\
\hline & BLH1 & & 5,89 & 3,63 & & 2,2 & 93,4 & 27,4 & 0 & 0 & 0 & \\
\hline & BLH1 & & 5,9 & 3,65 & & 3 & 94,4 & 27,5 & 0 & 0 & 0 & \\
\hline 1 & BLH1 & & 5,93 & 3,71 & & 2,9 & 85 & 27,6 & 0 & 0 & 0 & \\
\hline & BLH1 & & 5,9 & 3,82 & & 3 & 89 & 27,6 & 0 & 0 & 0 & \\
\hline & BLH1 & & 5,99 & 3,79 & & 2,9 & 69,4 & 27,7 & 0 & 0 & 0 & \\
\hline & BLH2 & & 5,45 & 2,6 & & 1,7 & 18,9 & 30,3 & 0 & 0 & 0 & \\
\hline & BLH1 & & 5,89 & 4,05 & & 2,9 & 87,2 & 27,8 & 0 & 0 & 0 & \\
\hline & BLH2 & & 5,56 & 2,94 & & 1,7 & 17,8 & 30,7 & 0 & 0 & 0 & ] \\
\hline & BLH2 & & 5,35 & 2.24 & & 1,8 & 18 & 29.9 & 0 & 0 & 0 & - \\
\hline $\operatorname{Rec}$ & cord: 14 & 4 & & 5429 & & D & of of & 5444 & & & & \\
\hline
\end{tabular}

Gambar 22 : Data Hasil Pengukuran Dalam Format TXT (atas) dan Format MDB (bawah).

Permintaan data melalui perangkat ponsel juga bisa dilakukan dengan menggunakan kata perintah yang telah ditentukan dengan format, yaitu : 
[ Onlimo 2010 nomor_urut ], dimana variabel nomor_urut adalah nomor urut registrasi ID Stasiun dalam tabel data, yaitu 1. Stasiun BLH1 (Muara Pela), 2. Stasiun BLH2 (Desa Semayang), 3. Stasiun BLH3 (Desa Melintang, dan 4. Stasiun BLH4 (Desa Nenggelam). Berikut ini adalah contoh permintaan data untuk keempat RTU.

- Onlimo 20101 : permintaan data stasiun BLH1

- Onlimo 20102 : permintaan data stasiun BLH2

- Onlimo 20103 : permintaan data stasiun BLH3

- Onlimo 20104 : permintaan data stasiun BLH4

Contoh hasil pengiriman datanya adalah sebagai berikut :

ST BLH1 : 03/04/2014 07:50:00 pH= 5,89, DO= 3,64 $\mathrm{mg} / \mathrm{l}, \mathrm{Cond}=2,8 \mathrm{~S} / \mathrm{m}$, Turb $=82,9 \mathrm{ntu}, \mathrm{Temp}=27,40 \mathrm{C}$, Sal $=0,00 \mathrm{ppt}, \mathrm{TDS}=0,0 \mathrm{mg} / \mathrm{L} * * *$ (C) Onlimo BPPT $* * *$

\subsection{Hasil Monitoring Kualitas Air}

Pemantauan harian mengasilkan pengiriman data 24 record data per hari dengan interval 1 jam sekali. Data yang diterima oleh aplikasi SMS Gateway kemudian disimpan dalam file database yang dapat dikelola menggunakan aplikasi pengolahan data online monitoring kualitas air. Pemantuan online dan realtime, pelaporan serta pemeliharaan data dapat dilakukan menggunakan aplikasi ini. Gambar-gambar berikut ini adalah beberapa contoh tampilan pemantuan realtime dalam bentuk angka maupun analisa grafik.

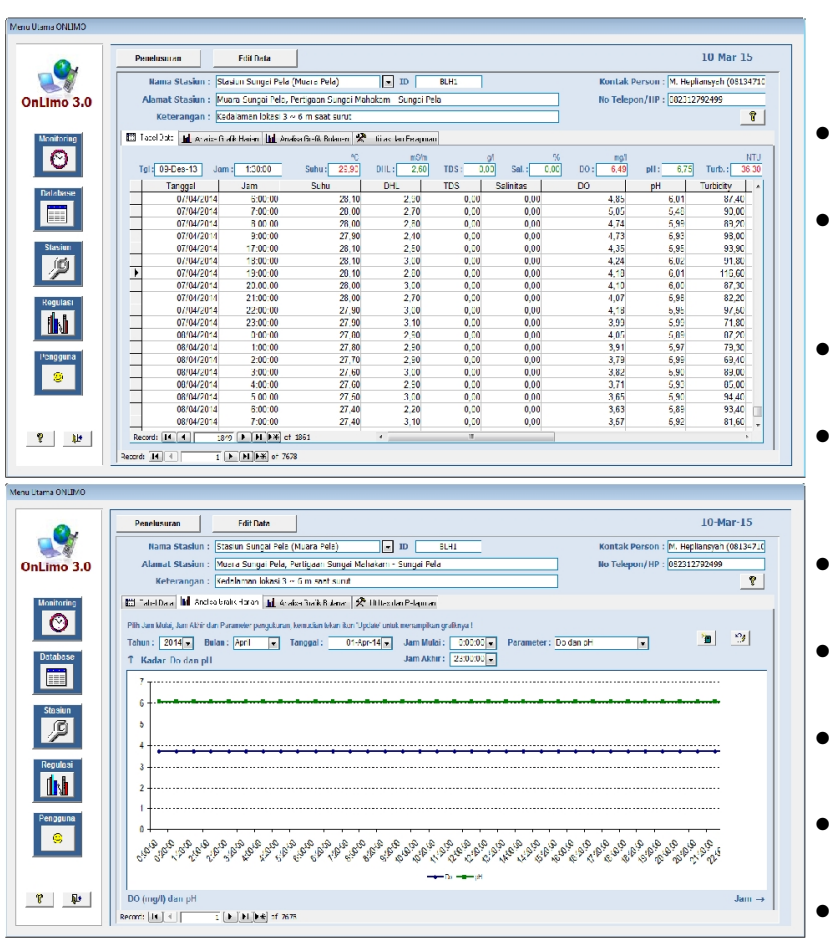

Gambar 23 : Pemantauan Harian Dalam Bentuk Angka Dan Analisa Grafik Di Salah Satu Stasiun Pantau.

\subsection{Pelatihan Operator}

Ada dua kelompok operator yang diberikan pelatihan, yaitu :

a) Operator lapangan yang berjumlah empat orang dari setiap lokasi pemantauan. Keempat operator ini diberikan beberapa kegiatan pelatihan di lapangan, yaitu :

- Pemasangan sistem peralatan yang terdiri dari data logger, sensor dan solar cell.

- Menyalakan, melihat status kerja, dan mematikan sistem peralatan data logger.

- Pengamatan kedipan lampu LED data logger untuk mengetahui status pendeteksian masingmasing komponen oleh data logger.

- Pengamatan status sinyal GSM modem di lokasi pemantauan.

- Pemeliharaan sensor, yaitu mengangkatnya, membersihkan, mengganti batere dan mengamati tanda / kode error pada LCD.

- Pemeliharaan permukaan solar cell dari tutupan kotoran, pengecekan kondisi aki kering dan pemeliharaan kabel power solar cell.

- Pemeliharaan keseluruhan sistem peralatan elektronik yang berada di rumah rakit dari serangga pengerat, semut, dan lain-lain.

- Pengamanan sistem peralatan dan rumah rakit di lokasi pemantauan dari tindakan pencurian.

b) Operator komputer pusat data yang didampingi oleh kepala bidang pengendalian pencemaran lingkungan di kantor BLH Kutai Kartanegara di Kota Tenggarong. Beberapa kegiatan pelatihan yang diberikan adalah :

- Menyalakan, melihat status kerja, dan mematikan sistem peralatan data logger.

Pengamatan kedipan lampu LED data logger untuk mengetahui status pendeteksian masingmasing komponen oleh data logger.

- Pengamatan status sinyal GSM modem di lokasi pemantauan.

Pengoperasian software SMS Gateway (mengaktifkan, menyambungkan ke sistem GSM modem, registrasi RTU, user SMS)

Memantau status data logger, sensor dan solar cell melalui komputer pusat data,.

Mengubah setting konfigurasi interval waktu pengukuran.

Pengelolaan data menggunakan software database online monitoring kualitas air.

Pembuatan laporan pemantuan kualitas air di keempat lokasi pemantuan.

Bersama-sama staf laboratorium melakukan kalibrasi sensor, penggantian DO cap, pengisian carian elektrolit, dan lain-lain. 


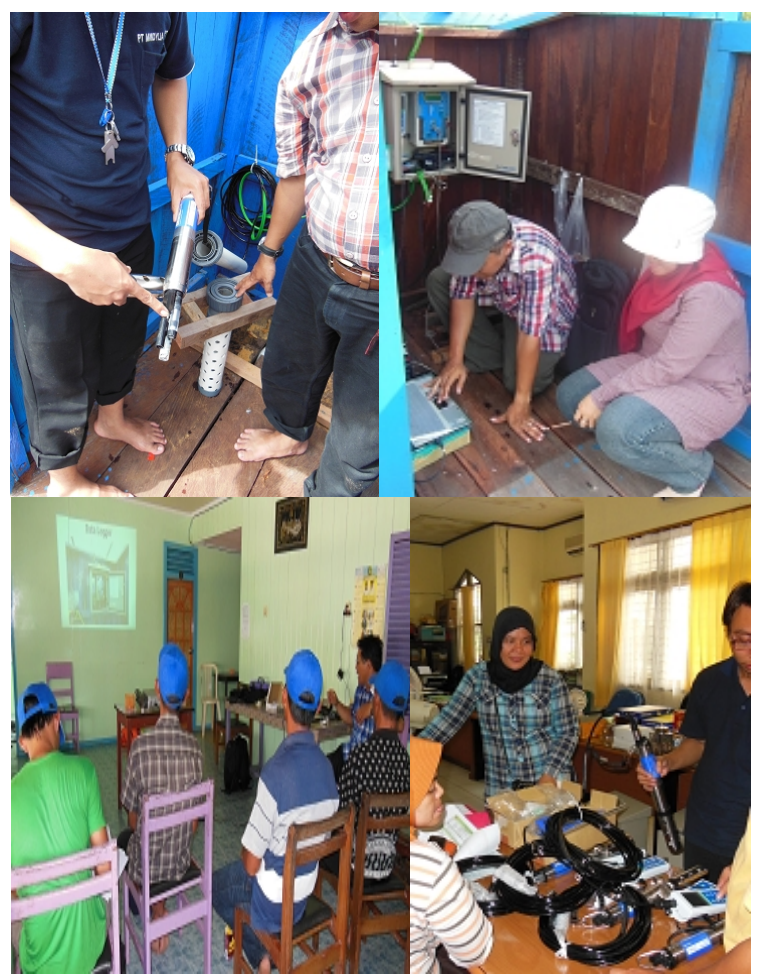

Gambar 24 : Pelatihan Operator Lapangan dan Operator Pusat Data.

\subsection{Permasalahan di Lapangan}

Lokasi pemantauan yang jauh dari pusat data, yaitu sekitar 6 jam perjalanan darat dari Kota Tenggarong menyulitkan tenaga ahli atau operator terlatih untuk membantu dalam proses pemeliharaan peralatan. Berikut ini adalah beberapa kendala dan permasalahan lain yang ada selama pemasangan di lapangan, yaitu :

- Lokasi pemantuan yang berada di danau dan jauh dari jangkauan BTS yang ada menyulitkan pemilihan lokasi yang aman dengan kualitas kekuatan sinyal GSM yang baik (minimal 7dB).

- Lokasi stasiun BLH1 di muara Sungai Pela berada di tepi sungai yang memiliki semak-semak yang cukup tinggi, sehingga pada saat pemasangan dan perawatan banyak terdapat serangga yang mengganggu operator dan mungkin dapat merusak sistem kelistrikan di dalam data logger.

- Beberapa bulan terpasang, solar cell pada stasiun BLH1 hilang dicuri, sehingga sistem RTU tidak bisa beroperasi.

- Lokasi stasiun BLH3 di desa Semayang berada berdekatan dengan pengerajin kerupuk ikan, dikhawatirkan lokasi tersebut banyak terdapat hewan pengerat seperti tikus yang mungkin dapat masuk ke dalam rumah rakit dan dapat merusak kabel di dalamnya.

- Beberapa bulan terpasang, kabel data pada stasiun BLH3 yang menghubungkan sensor ke data logger putus akibat digigit hewan pengerat tikus.

- Berbeda dengan sensor YSI yang lebih dulu pernah diintegrasikan dengan data logger ini, sensor WQC-24 yang digunakan di keempat lokasi pemantaun memerlukan power suplai khusus 5V DC untuk pengoperasiannya. Pada awal pemasangannya digunakan batere alkaline A3 yang hanya mampu beroperasi selama 7-10 hari terus menerus. Hal ini menyulitkan operator lapangan untuk terus menyediakan batere cadangan di lokasi.

- Pusat data di Kantor BLH Kutai Kartanegara di Kota Tenggarong dalam satu hari bisa beberapa kali terjadi pemadaman listrik, hal ini dapat menyebabkan komputer pusat data mati secara tiba-tiba dan mengakibatkan kerusakan sistem software pada komputer pusat data.

- Belum dibentuknya unit pengelola stasiun online monitoring kualitas air menyebabkan tidak adanya staf yang khusus ditugaskan untuk melakukan pemeliharaan terhadap jalannya sistem online monitoring, sehingga penanganan jika terjadi kegagalan sistem monitoring tidak dapat dilaksanakan dengan cepat.

\section{KESIMPULAN}

Kesimpulan yang dapat ditarik dari kegiatan implementasi pemantauan kualitas air di empat lokasi pemantauan di Danau Semayang dan Danau Melintang berikut saran yang diberikan adalah sebagai berikut :

- Sistem peralatan online monitoring kualitas air yang telah dipasang di keempat lokasi stasiun pemantauan di Danau Semayang dan Melintang dapat beroperasi dengan baik dengan jumlah pengiriman data masing-masing 24 record data dalam satu hari. Sistem ini sangat cocok untuk memantau kualitas perairan yang berada di remote area seperti di kedua danau.

- Penentuan lokasi pemasangan peralatan sangat perlu memperhatikan kekuatan sinyal GSM salah satu operator seluler. Kekuatan sinyal yang dibutuhkan agar dapat mengirimkan data pengukuran melalui SMS minimal adalah sebesar 7 dB. Untuk keperluan pengiriman gambar, kekuatan sinyal GSM yang diperlukan berada di antara $25 \mathrm{~dB} \sim 31 \mathrm{~dB}$ dengan tipe koneksi HSDPA (PTL-KLHK, 2014).

- Untuk menghindari masuknya serangga ke dalam ruang panel, disarankan menggunakan box panel dari bahan plastik / PVC yang kedap air dengan bagian bawah panel ditutup serapat mungkin. Untuk mengeluarkan kabel digunakan cable glands, sehingga kabel dapat terpasang dengan rapih dan kuat. 
- Perlu dibuat regulator 5V DC seperti gambar rangkaian elektronik di bawah ini untuk mensuplai tegangan listrik DC ke sensor WQC-24, sehingga penggantian batere seminggu sekali tidak diperlukan lagi. Untuk mengamankan rangkaian dari posisi terbalik pada saat pemasangan, perlu dipasang sekring 0.5A untuk pemutus arus jika terjadi korsleting (Galih Setiaji, 2014).

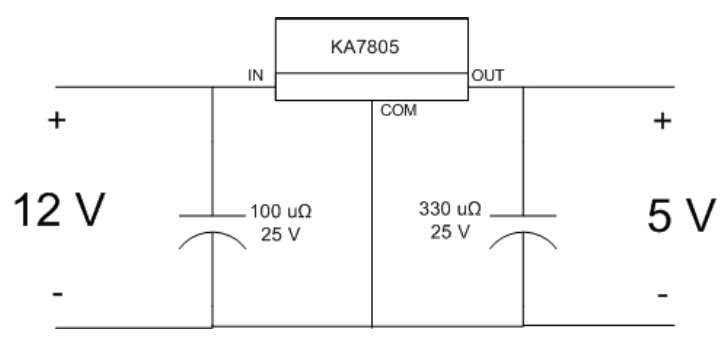

Gambar 25. Box PVC dan Cable Glands.

- Kendala sering padamnya ketersediaan listrik PLN dapat diatasi dengan membangun sistem backup kelistrikan, dapat berupa mesin genset atau menggunakan sistem solar cell. Dengan asumsi penggunaan kebutuhan listrik 500watt selama 24 jam untuk mengoperasikan komputer pusat data $(12 \mathrm{KWH})$, dengan optimal penyinaran selama 4,5 jam dan efisiensi 80\%, maka dibutuhkan solar cell dengan kapasitas $2.666 \mathrm{Wp}$ atau setera dengan 34 buah panel sel surya masing-masing 100wp. Sedangkan batere yang dibutuhkan adalah 13 buah dengan masingmasing 100 Ah (Galih Setiaji, 2014)

- Tidak adanya unit kerja atau staf yang khusus ditugaskan untuk mengoperasikan sistem online monitoring ini, menjadi kelemahan sistem kelembagaan BLHD Kutai Kartanegara. Kegagalan sistem yang terjadi seperti padamnya listrik PLN atau pulsa GSM modem pada RTU yang habis tidak dapat sesegera mungkin di atasi, sehingga data pengukuran kualitas air di kedua danau tidak dapat secara realtime masuk ke pusat data. Untuk itu disarankan agar dibentuk unit kerja khusus yang beranggotakan beberapa orang staf dengan kemampuan SDM yang cukup untuk mengoperasikan jalannya sistem secara menyeluruh.

\section{DAFTAR PUSTAKA}

- Wikipedia, Ensiklopedia Bebas, http://id.wiki pedia.org/wiki/Danau_Semayang, 2014

- Limnologi LIPI, Danau Semayang, Melintang dan Jempang, http://danau.limnologi.lipi.go.id/danau /profil.php?id_danau=kal_smyg\&tab=gambaran \%20umum, 2014.

- Wikipedia, Ensiklopedia Bebas, http://id.wiki pedia.org/wiki/Danau_Melintang, 2014.

- Heru D.W. dan Bayu B., Sistem Manajemen Komunikasi Data Jarak Jauh Berbasis Teknologi SMS dan Radio Telemetri Untuk Pemantauan Kualtias Air, JTL Vol 7 No. 2 Mei 2006.

- Bayu B. dan Heru D.W., Petunjuk Operasional Sistem Online Monitoring Kualitas Air Berbasis SMS Versi 3.0, PTL - BPPT, 2013.

- Heru Dwi Wahjono, Petunjuk Operasional Software Database Online Monitoring Kualitas Air di Danau Semayang dan Melintang Versi 3.0, Pusat Teknonologi Lingkungan - BPPT, 2013.

- Gubernur Kaltim, Perda Prov Kaltim No. 2 Tahun 2011 Tentang Pengendalian Kualitas Air dan Pengendalian Pencemaran Lingkungan, 2011.

- PTL-KLHK, Pengkajian Dan Penerapan Sistem Monitoring Pengendalian Pencemaran DAS Ciliwung, 2014.

- Galih Setiaji, Perhitungan Kebutuhan Solar Cell dan Aki Kering pada Pusat Data Sistem Online Monitoring, 2014. 


\section{LAMPIRAN:}

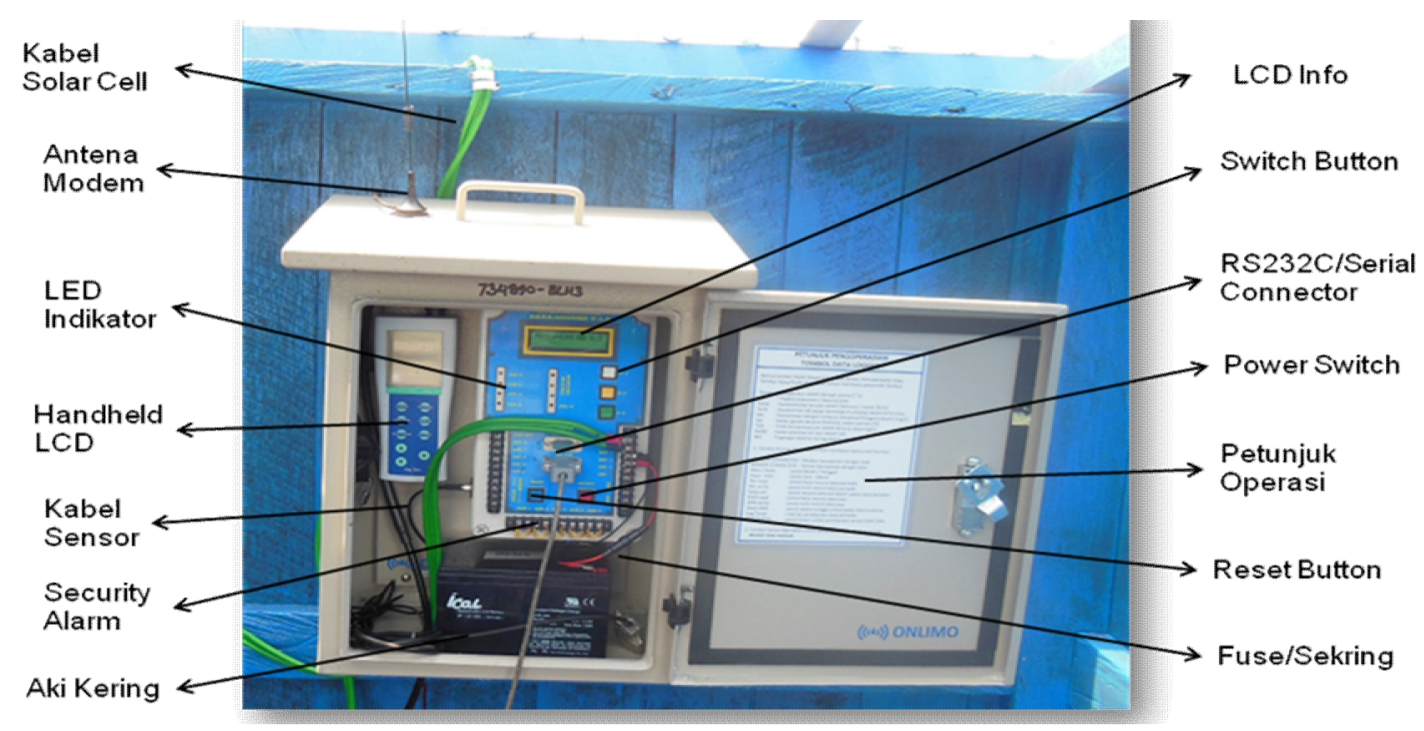

Gambar 26 : Komponen Data Logger yang Terpasang.

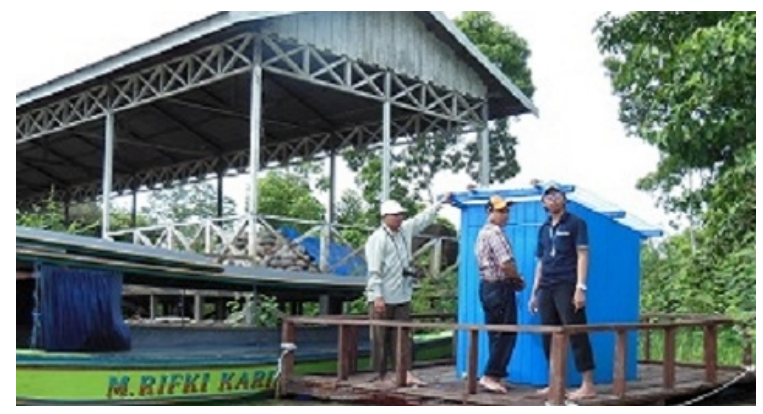

Stasiun BLH1 Muara Pela

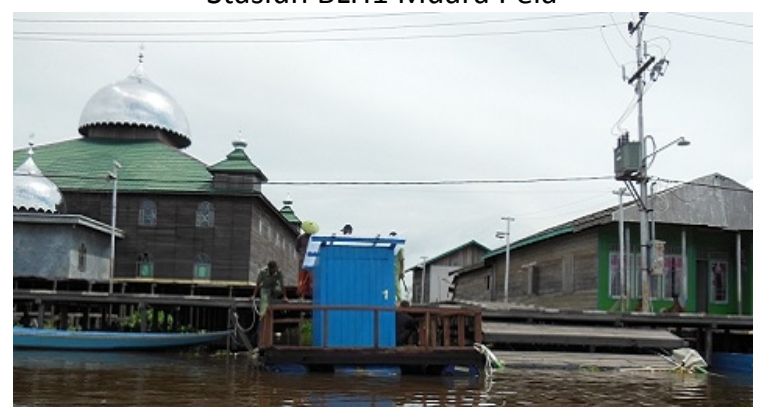

Stasiun BLH3 Desa Melintang

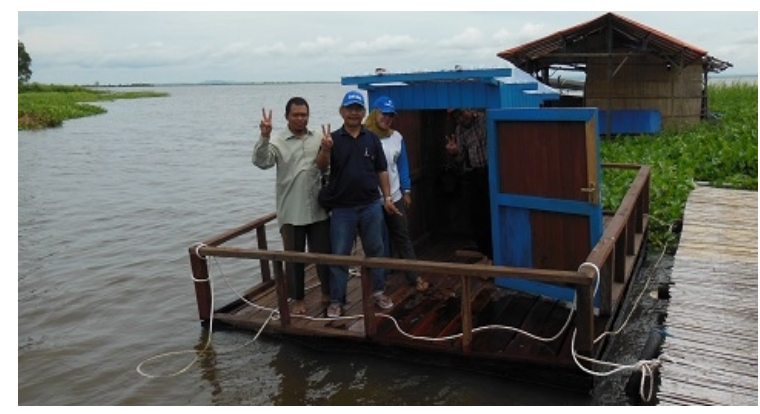

Stasiun BLH2 Desa Semayang

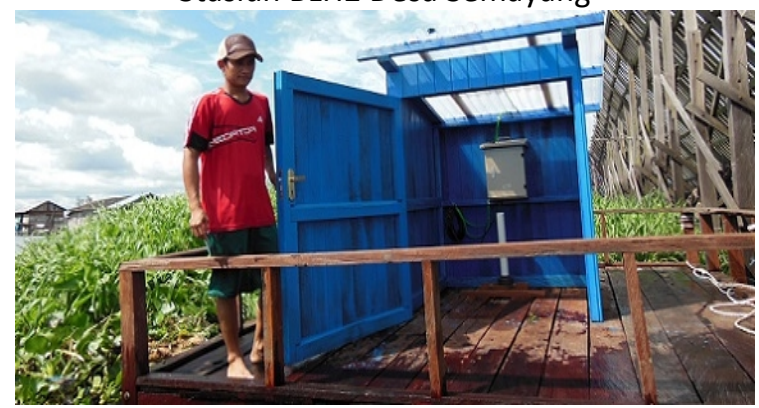

Stasiun BLH4 Nenggelam

Gambar 27 : Stasiun Online Monitoring di Empat Lokasi di Danau Semayang dan Melintang. 
Heru Dwi Wahjono : Pemantauan Kualtias Air Danau Semayang dan DanauMelintang di Kabupaten ... JAI Vol. 8 No. 1, 2015 